\title{
SCREENING FOR ANTIMICROBIAL ACTIVITY AMONG BACTERIA ISOLATED FROM THE AMAZON BASIN
}

\author{
Amanda S. Motta; Florencia Cladera-Olivera; Adriano Brandelli* \\ Laboratório de Bioquímica e Microbiologia Aplicada, Departamento de Ciência de Alimentos, ICTA, Universidade Federal do \\ Rio Grande do Sul, 91501-970 Porto Alegre, Brasil
}

Submitted: June 06, 2004; Returned to authors for corrections: October 13, 2004; Approved: December 20, 2004

\begin{abstract}
Bacteria producing antimicrobial activity were identified among 86 isolates from aquatic environments of Brazilian Amazon Basin. Antimicrobial activity against at least one indicator strain was detected for 59 isolates (68.6\%). Inhibitory activity was mostly against Gram-positive bacteria, such as Listeria monocytogenes and Bacillus cereus. The antimicrobial substances produced by 19 strains that showed higher inhibitory activity were partially characterized. These antimicrobial substances showed thermal resistance for up to $100^{\circ} \mathrm{C}$ and partial resistance to proteolytic treatment. Some antimicrobials were partially resistant to pronase $\mathrm{E}$ at $2 \mathrm{mg} \mathrm{ml}^{-1}$ or to treatment with trichloroacetic acid. Detection of antimicrobial activity on polyacrylamide gels revealed that the molecular weight of the compounds was lower than $14 \mathrm{kDa}$. Several strains showed antibacterial activity, which in some cases appear to be related to antimicrobial peptides. The potential of these microorganisms to produce useful antimicrobial compounds is great and must be better explored.
\end{abstract}

Key words: antimicrobial activity, Listeria monocytogenes, bacteriocins, Amazon Basin

\section{INTRODUCTION}

Production of antimicrobial compounds seems to be a general phenomenon for most bacteria. An admirable array of microbial defense systems are produced, including broad-spectrum classical antibiotics, metabolic by-products such as organic acids, and lytic agents such as lysozyme. In addition, several types of protein exotoxins, and bacteriocins, which are biologically active peptide moieties with bactericidal mode of action, were described $(20,26)$. This biological arsenal is remarkable in its diversity and natural abundance, since some substances are restricted to some bacterial groups while other are widespread produced (20).

The search for new antimicrobial agents is a field of utmost importance. The prevalence of antimicrobial resistance among key microbial pathogens is increasing at an alarming rate worldwide (22). Current solutions involve development of a more rationale approach to antibiotic use and discover of new antimicrobials, but the problem of antibiotic resistance is increasing globally and may render the current antimicrobial agents insufficient to control at least some bacterial infections (3).

Amazon basin is a source of enormous biological diversity, which is scarcelly studied. Particularly, few reports on microbial life are described (5). More recently, the characterization of microorganisms with biotechnological interest has been reported $(1,6)$, however, the production of antimicrobials by bacteria isolated in this region is poorly described (7). The aim of this work was to investigate the antimicrobial activity of bacteria isolated from aquatic environments neighboring Manaus, at the Brazilian Amazon Basin.

\section{MATERIALS AND METHODS}

\section{Bacterial cultures}

The strains used in this work included bacteria from aquatic environments of the Amazon region, near Manaus, Brazil (306' S, $\left.60^{\circ} 01^{\prime} \mathrm{W}\right)$, and they were kindly provided by Dr. Spartaco Astolfi Filho (Universidade Federal do Amazonas, Brazil). Indicator

*Corresponding author. Mailing address: ICTA-UFRGS, Av. Bento Gonçalves, 9500. 91501-970, Porto Alegre, RS, Brasil. E-mail: abrand@ufrgs.br 
microorganisms for the characterization of antimicrobial activity were strains from collections and are listed in Table 1. Bacteria were maintained as stock cultures frozen at $-21^{\circ} \mathrm{C}$ in BHI broth (Difco, Detroit, USA) supplemented with $20 \%$ glycerol. Strains were propagated twice before used in experiments. Morphological and biochemical characterization was performed as described elsewhere $(8,13)$.

\section{Growth and production of antimicrobial activity}

Bacteria were grown in $250 \mathrm{ml}$ Erlenmeyer flasks containing $100 \mathrm{ml}$ of BHI broth incubated for $48 \mathrm{~h}$ at $31 \pm 1^{\circ} \mathrm{C}$ in shaker at 125 cycles/min. After growth, culture media were centrifuged at 10,000 $\mathrm{g}$ for $15 \mathrm{~min}$, and the supernatants were filtered through $0.22 \mu \mathrm{m}$ membranes (Millipore, Bedford, USA). The resulting filtrates were used to evaluate antimicrobial activity. The $\mathrm{pH}$ of the filtrates was measured showing values always between 7.0 to 8.0.

\section{Detection of antimicrobial activity}

Antibacterial activity was determined essentially as described elsewhere (14). An aliquot of $20 \mu \mathrm{l}$ cell-free culture supernatant was applied on cellulose disks $(6 \mathrm{~mm})$ on BHI agar plates previously inoculated with each indicator strain suspension, which corresponded to a $0.5 \mathrm{McFarland}$ turbidity standard solution. Plates were incubated for $24 \mathrm{~h}$ at optimal temperature for the test organism (Table 1). The inhibition zones around the disks were measured.

\section{Effect of heat and enzymes on antimicrobial activity}

Proteolytic enzymes were tested on cell-free supernatant. Samples of $1 \mathrm{ml}$ were treated at $37^{\circ} \mathrm{C}$ for $1 \mathrm{~h}$ with $2 \mathrm{mg} \mathrm{ml}^{-1}$ of either trypsin (Sigma, St. Louis, USA) or pronase E (Sigma). Samples were then boiled for 2 min to inactivate the enzyme. To analyze thermal stability, samples of the supernatants were exposed to temperatures ranging 40 to $100^{\circ} \mathrm{C}$ for $15 \mathrm{~min}$ and $121^{\circ} \mathrm{C} / 105 \mathrm{kPa}$ for $15 \mathrm{~min}$ before being tested for antimicrobial activity. Trichloroacetic acid (TCA) was added to the filtrates

Table 1. Antimicrobial activity of bacteria isolated from Amazon basin.

\begin{tabular}{lcc}
\hline Indicator strain $^{\mathrm{a}}$ & $\begin{array}{c}\text { Temperature } \\
\left({ }^{\circ} \mathrm{C}\right)\end{array}$ & $\begin{array}{c}\text { Inhibitory } \\
\text { strains, n (\%) }\end{array}$ \\
\hline Corynebacterium fimi NCTC 7547 & 37 & $44(51.2)$ \\
Listeria monocytogenes ATCC 7644 & 37 & $43(50.0)$ \\
Bacillus cereus ATCC 9634 & 37 & $55(64.0)$ \\
Lactobacillus acidophilus ATCC 4356 & 30 & $47(54.7)$ \\
Staphylococcus aureus ATCC 25923 & 37 & $2(2.3)$ \\
Escherichia coli ATCC 25922 & 37 & $1(1.2)$ \\
Salmonella Enteritidis ATCC 13076 & 37 & $1(1.2)$ \\
\hline
\end{tabular}

${ }^{\mathrm{a}}$ Indicator strains were grown on BHI agar plates for $24 \mathrm{~h}$. to reach a working concentration of $100 \mathrm{mg} \mathrm{ml}^{-1}$ and the samples were incubated for $2 \mathrm{~h}$ at $4^{\circ} \mathrm{C}$. After treatment with TCA, samples were centrifuged at 10,000 $\mathrm{x} g$ for $5 \mathrm{~min}$ and the supernatant was neutralized to $\mathrm{pH} 7.0$ before testing for antimicrobial activity. After the treatments, the samples were tested for antimicrobial activity against L. monocytogenes ATCC 7644.

\section{Direct detection on gels}

Aliquots of $1 \mathrm{ml}$ of culture filtrates were freeze-dried. Samples were suspended in $0.1 \mathrm{ml} 125 \mathrm{mM}$ tris $\mathrm{pH} 6.8$ containing $0.1 \%$ SDS, $20 \%$ glycerol, and then applied to $14 \%$ polyacrylamide gels. Electrophoresis was carried out as described elsewhere (11) using a Mighty Small II apparatus (Hoefer Scientific, San Francisco, USA) and $20 \mathrm{~mA}$ per gel. After running, the gels were washed with sterile distilled water for removal of SDS and then flooded on plates containing tempered BHI agar with $10^{6}$ $\mathrm{cfu} / \mathrm{ml}$ L. monocytogenes. Detection of antimicrobial activity was carried out as described by Naclerio et al. (15).

\section{RESULTS}

Screening of the antimicrobial activity of 86 isolates was carried out against 7 indicator strains. Inhibitory activity against at least one indicator strain was detected for 59 isolates $(68.6 \%)$. The majority of strains (64\%) inhibited B. cereus growth (Table $1)$. Forty three isolates $(50 \%)$ inhibited the growth of $L$. monocytogenes and the strains $\mathrm{P} 2$ and $\mathrm{P} 31 \mathrm{~A}$ presented the highest inhibition zones (17 mm). Staphylococcus aureus was inhibited by only two isolates, P45B and P31A, while antimicrobial activity against Escherichia coli and Salmonella Enteritidis was detected only for isolates P10 and P30, respectively.

Those bacteria producing inhibition zones higher than 10 $\mathrm{mm}$ against at least two microorganisms were selected for further characterization of their antimicrobial activity. Based on this criteria 19 bacterial isolates were selected. The isolates were straight Gram-positive rods with endospores, and were strongly catalase positive. Additional biochemical tests indicated that these isolates belonged to the genus Bacillus. The antimicrobial substances were partially resistant to proteolytic treatment (Table 2), being only the antimicrobial substances produced by strains P8A and P34 sensitive to both trypsin and pronase. The activity produced by 11 strains, including P8A and P34, was completely lost after treatment with TCA. The antimicrobial activity of all filtrates was heat resistant for up to $100^{\circ} \mathrm{C}$ for 15 min. After autoclaving, 14 filtrates still presented some residual activity, and 5 filtrates completely lost the activity after this treatment.

Direct detection of antimicrobial activity on polyacrylamide gels was carried out. All the substances showed inhibitory activity against $L$. monocytogenes, and presented a molecular weight lower than $14 \mathrm{kDa}$. 
Table 2. Partial characterization of 19 selected isolates with antimicrobial activity.

\begin{tabular}{ccc}
\hline Isolate & Inhibitory spectra $^{\text {a }}$ & Properties $^{\text {b }}$ \\
\hline P2 & Cf, $\mathrm{Lm}, \mathrm{La}, \mathrm{Bc}$ & $\mathrm{TH}$ \\
P5 & Cf, Lm, La, Bc & TPH \\
P7 & Cf, Lm, La, Bc & TH \\
P8A & Lm, La, Bc & H \\
P10 & Cf, Lm, Ec, Bc & TH \\
P21 & Cf, Lm, La, Bc & TAH \\
P16 & Cf, Lm, La, Bc & TAH \\
P34 & Cf, Lm, La, Bc & H \\
P35 & Cf, Lm, La, Bc & TPH \\
P38 & Lm, La, Bc & TPAH \\
P39A & Lm, La, Bc & TAH \\
P30 & Cf, Se, Lm, La, Bc & TH \\
P48 & Lm, La, Bc & TPAH \\
P51 & Cf, Lm, La, Bc & TPAH \\
P52 & Cf, Lm, La, Bc & TPAH \\
P71 & Cf, Lm, La, Bc & TH \\
622 & Cf, Lm, La, Bc & TH \\
P45B & Cf, Sa, Lm, La, Bc & TPH \\
P31A & Cf, Sa, Lm, La, Bc & TH \\
\hline
\end{tabular}

${ }^{a} \mathrm{Cf}$, Corynebacterium fimi; Sa, Staphylococcus aureus; Ec, Escherichia coli; Se, Salmonella Enteritidis; Lm, Listeria monocytogenes; La, Lactobacillus acidophilus; $\mathrm{Bc}$, Bacillus cereus; ${ }^{\mathrm{b}}$ Antimicrobial activity was resistant to the following treatments: $(\mathrm{T})$ trypsin; $(\mathrm{P})$ pronase $\mathrm{E}$; (A) trichloroacetic acid; $(\mathrm{H})$ heating for $15 \mathrm{~min}$ at $100^{\circ} \mathrm{C}$.

\section{DISCUSSION}

Screening for antimicrobial activity of bacteria isolated from Amazon has not been described yet. This study has demonstrated that production of antimicrobial substances is widespread among these bacterial strains. Almost $70 \%$ of the isolates exhibited antimicrobial activity against one or more indicator bacteria. This corresponds to a higher proportion than often described in other investigations $(9,12,21)$. Among lactic acid bacteria isolated from raw milk, 82 of 298 strains $(27.5 \%)$ displayed bacteriocin activity (21), while $8.7 \%$ of $S$. aureus strains isolated from cattle produced antimicrobial substances (17). De Vuyst et al. (9) found that 122 of 426 Enterococcus strains $(28.6 \%)$ of various origins produced enterocin. Antimicrobial evaluation of cyanobacteria demonstrated that $16.3 \%$ was active against Gram-positive and 5.8\% against Gramnegative bacteria, while $10.5 \%$ possessed antifungal activity (12). Bacilli isolated from the brittlestar Amphipholis gracillima exhibited a high range of complete inhibition of several test bacteria (24). The high proportion of antimicrobial producing strains may be associated with an ecological role, playing a defensive action to maintain their niche, or enabling the invasion of a strain into an established microbial community.

The inhibitory effect was mostly against Gram-positive bacteria. Most strains inhibited B. cereus. The antimicrobial spectra, essentially restricted to Gram-positive bacteria, may suggest that the produced antimicrobial substances are related to a specific feature of Gram-positive bacteria. It is well known that activity of bacteriocins produced by Gram-positive bacteria is restricted to other Gram-positive bacteria (20).

The $\mathrm{pH}$ values of the crude antimicrobial substances indicate that the inhibitory effect was not due to production of organic acids. Most of these substances were partially or completely inactivated by proteases and TCA, suggesting that a protein moiety is involved in the activity. This may indicate that bacteriocin-like substances are implied in antimicrobial activity. These substances showed high thermal resistance and low molecular weight, which are characteristics of small hydrophobic peptides that constitute class II bacteriocins (20).

Although these bacteria were not yet identified to the species level, morphological and biochemical characteristics indicate they belong to the genus Bacillus. A variety of antimicrobial compounds are produced by members of the genus Bacillus, many of these identified as peptides, lipopeptides and phenolic derivatives (16). A wide range of antimicrobial substances produced by Bacillus spp. isolated from arthropods were recently described, including aromatic acids, acetylamino acids (amino acid analogs), and peptides (10). Bacteriocin-like substances have been related to Bacillus spp. isolated from soil $(4,18)$ and vegetal tissues $(2,27)$. Isocoumarin antibiotics are produced by Bacillus spp., as demonstrated for B. subtilis strains from different habitats and geographic origins (19). A siderophore with wide range of antibacterial spectrum is produced by Bacillus sp. NM12 from fish intestine (25) and aminopolyol antibiotic by soil isolates of B. cereus (23). Although several antimicrobial substances described in this work appear to be peptides, other substances can not be ruled out since resistance to proteases and even to TCA was observed in some cases.

Results of this study indicate that the potential of these microorganism to produce antimicrobial compounds that can be useful for many applications is great and must be better explored.

\section{RESUMO}

\section{Atividade antimicrobiana entre bactérias isoladas da Bacia Amazônica}

Bactérias produtoras de atividade antimicrobiana foram identificadas entre 86 isolados de ambientes aquáticos da Bacia Amazônica. Destes, 59 isolados (68.6\%) apresentaram atividade antimicrobiana contra pelo menos uma bactéria indicadora. A 
atividade inibitória foi principalmente observada contra bactérias Gram-positivas, como Listeria monocytogenes e Bacillus cereus. As substâncias antimicrobianas produzidas por 19 linhagens que demonstraram maior atividade inibitória foram parcialmente caracterizadas, apresentando resistência térmica até $100^{\circ} \mathrm{C}$ e resistência parcial ao tratamento proteolítico. Algumas substâncias foram parcialmente inativadas somente quando tratadas com ácido tricloroacético ou com pronase E na concentração de $2 \mathrm{mg} \mathrm{ml}^{-1}$. A detecção da atividade antimicrobiana em géis de poliacrilamida mostrou que os compostos apresentaram peso molecular inferior à $14 \mathrm{kDa}$. Várias linhagens apresentaram atividade antibacteriana, que em alguns casos estaria relacionada com peptídios antimicrobianos. O potencial destes microrganismos para produzir substâncias antimicrobianas é grande e merece ser mais explorado.

Palavras-chave: atividade antimicrobiana, Listeria monocytogenes, bacteriocinas, Bacia Amazônica

\section{REFERENCES}

1. Bastos, A.E.R.; Moon, D.H.; Rossi, A.; Trevors, J.T.; Tsai, S.M. Salttolerant phenol-degrading microorganisms isolated from Amazonian soil samples. Arch. Microbiol., 174:346-352, 2000.

2. Bechard, J.; Eastwell, K.C.; Sholberg, P.L.; Mazza, G.; Skura, B. Isolation and partial chemical characterization of an antimicrobial peptide produced by a strain of Bacillus subtilis. J. Agric. Food Chem., 46:5355-5361, 1998.

3. Bhavnani, S.M.; Ballow, C.H. New agents for Gram-positive bacteria. Curr. Op. Microbiol., 3:528-534, 2000.

4. Bizani, D.; Brandelli, A. Characterization of a bacteriocin produced by a newly isolated Bacillus sp. strain 8A. J. Appl. Microbiol., 93:512-519, 2002.

5. Borneman, J.; Triplett, E.W. Molecular microbial diversity in soils from Eastern Amazonia: evidence of unusual microorganisms and microbial population shifts associated with deforestation. Appl. Environ. Microbiol., 63:2647-2653, 1997.

6. Chies, J.M.; Dias, A.C.O.; Maia, H.M.M.; Astolfi-Filho, S. BanAI a new isoschizomer of the type II restriction endonuclease HaeIII discovered in a Bacillus anthracis isolate from Amazon basin. FEMS Microbiol. Lett., 215:97-101, 2002.

7. Cladera-Olivera, F.; Caron, G.R.; Brandelli, A. Bacteriocin-like substance production by Bacillus licheniformis strain P40. Lett. Appl. Microbiol., 38:251-256, 2004.

8. Clauss, D.; Berkeley, R.C.W. Genus Bacillus Cohn 1872. In: Sneath, P.H.A. (ed.). Bergey's Manual of Determinative Bacteriology, vol. 2. Williams \& Wilkins, Baltimore, 1986, p.1105-1141.

9. De Vuyst, L.; Foulquié Moreno, M.R.; Revets, H. Screening for enterocins and detection of hemolysin and vancomycin resistance in enterococci of different origins. Int. J. Food Microbiol., 84:299-318, 2003.
10. Gebhardt, K.; Schimana, J.; Müller, J.; Fiedler, H.P.; Kallenborn, H.G.; Holzenkämpfer, M.; Krastel, P.; Zeeck, A.; Vater, J.; Höltzel, A.; Schmid, D.G.; Rheinheimer, J.; Dettner, K. Screening for biologically active metabolites with endosymbiotic bacilli isolated from arthropods. FEMS Microbiol. Lett., 217:199-205, 2002.

11. Hames, B.D.; Rickwood, D. Gel electrophoresis of proteins. IRL Press, Oxford, 1981, 290p.

12. Jaki, B.; Orjala, J.; Burgi, H.R.; Sticher, O. Biological screening of cyanobacteria for antimicrobial and molluscicidal activity, brine shrimp lethality, and cytotoxicity. Pharm. Biol., 37:138-143, 1999.

13. MacFaddin, J.F. Biochemical test for identification of medical bacteria. Lippincot, Williams \& Wilkins, Baltimore, 2000, 912p.

14. Motta, A.S.; Brandelli, A. Characterization of an antimicrobial peptide produced by Brevibacterium linens. J. Appl. Microbiol., 92:63-70, 2002.

15. Naclerio, G.; Ricca, E.; Sacco, M.; De Felice, M. Antimicrobial activity of a newly identified bacteriocin of Bacillus cereus. Appl. Environ. Microbiol., 59:4313-4316, 1993.

16. Nakano, M.M.; Zuber, P. Molecular biology of antibiotic production in Bacillus. Crit. Rev. Biotechnol., 10:223-240, 1990.

17. Oliveira, S.S.; Póvoa, D.C.; Nascimento, J.S.; Pereira, M.S.V.; Siqueira, J.P.; Bastos, M.C.F. Antimicrobial substances produced by Staphylococcus aureus strains isolated from cattle in Brazil. Lett. Appl. Microbiol., 27:229-234, 1998.

18. Oscariz, J.C.; Lasa, I.; Pisabarro, A.G. Detection and characterization of cerein 7, a new bacteriocin produced by Bacillus cereus with a broad spectrum of activity. FEMS Microbiol. Lett., 178:337-341, 1999.

19. Pinchuk, I.V.; Bressollier, P.; Sorokulova, I.B.; Verneuil, B.; Urdaci, M.C. Amicoumacin antibiotic production and genetic diversity of Bacillus subtilis strains isolated from different habitats. Res. Microbiol., 153:269-276, 2002.

20. Riley, M.A.; Wertz, J.E. Bacteriocins: evolution, ecology, and application. Annu. Rev. Microbiol., 56:117-137, 2002.

21. Rodríguez, E.; González, B.; Gaya, P.; Nuñez, M.; Medina, M. Diversity of bacteriocins produced by lactic acid bacteria isolated from raw milk. Int. Dairy J., 10:7-15, 2000.

22. Singer, R.S.; Finch, R.; Wegener, H.C.; Bywater, R.; Walters, J.; Lipsitch, M. Antibiotic resistance - the interplay between antibiotic use in animals and human beings. Lancet Infect. Dis., 3:47-51, 2003.

23. Stabb, E.V.; Jacobson, L.M.; Handelsman, J. Zwittermicin Aproducing strains of Bacillus cereus from diverse soils. Appl. Environ. Microbiol., 60:4404-4412, 1994.

24. Strahl, E.D.; Dobson, W.E.; Lundie, L.L. Isolation and screening of brittlestar-associated bacteria for antibacterial activity. Curr. Microbiol., 44:450-459, 2002.

25. Sugita, H.; Hirose, Y.; Matsuo, N.; Deguchi, Y. Production of the antibacterial substance by Bacillus sp. NM12, an intestinal bacterium of Japanese coastal fish. Aquaculture, 165:269-280, 1998.

26. Yeaman, M.R.; Yount, N.Y. Mechanism of antimicrobial peptide action and resistance. Pharmacol. Rev., 55:27-55, 2003.

27. Yoshida, S.; Hiradate, S.; Tsukamoto, T.; Hatakeda, K.; Shirata, A. Antimicrobial activity of culture filtrate of Bacillus amyloliquefaciens RC-2 isolated from mulberry leaves. Phytopathology, 91:181-187, 2001 . 